\title{
Short Presentation of the Studies on Microbial Metabolites as Eco Friendly Insecticides against Halicoverpa armigera
}

\section{Divya Srivastava ${ }^{1 *}$, Adesh Kumar ${ }^{1}$, Poonam C. Singh ${ }^{2}$, Suchi Srivastava ${ }^{2}$, Shalini Srivastava ${ }^{1}$, Ashutosh Tiwari ${ }^{1}$, Praveen Tiwari ${ }^{1}$, Bhawna Mathur ${ }^{1}$, Jasvant Singh ${ }^{1}$ and Arun Kumar ${ }^{1}$}

${ }^{1}$ Department of Plant Molecular Biology and Genetic Engineering, Narendra Deva

University of Agriculture and Technology, Faizabad, U.P., India

${ }^{2}$ Division of Plant Molecular Interaction, C.S.I.R-

National Botanical Research Institute-CSIR, Lucknow, U.P., India

*Corresponding author

\section{A B S T R A C T}

\section{Keywords}

Biopecticide, Pod

borer, Halicoverpa

armigera, Microbial

biocontrol of insect,

Chemical pesticide.

Article Info

Accepted:

28 October 2017

Available Online:

10 December 2017
Today crop pests have become a major concern for the farmers across the world. Helicoverpa armigera commonly known as Gram Pod-Borer is an economic important insect pest of gram crop, which was used to be treated with chemical insecticides. Due to misuse and overuse of these chemical insecticides, resistance is being developed in many insects resulting in increased survival rate of the insect pests. There is an urgent need for alternatives of these chemical insecticides. Bioinsecticides are eco-friendly insect/pest control which is obtained from naturally occurring substances (biochemicals), microbes and plants. Before developing a new insecticide, the scenario of $H$. armigera and its bio-control should be presented with the help of some prior studies. This paper describes the national and international research work based on the microbial pesticide/ insecticides against $H$. armigera.

\section{Introduction}

Agriculture is the backbone of Indian economy which has gone through immense changes in the second half of the twentieth century. Adoption of technologies, high yielding varieties, and agrochemicals between 1960 to 2000 lead to 'The Green Revolution' increasing the crop yield per hectare. Today crop pests have become a major concern for the farmers across the world. Helicoverpa armigera is commonly known as Gram PodBorer.
Productivity of Gram crop is strongly affected by $H$. armigera, which damages $90-95 \%$ crop during favorable weather conditions, due to its high fecundity, migratory and polyphagus nature, and its resistance to insecticides. Yield losses of $400 \mathrm{~kg} / \mathrm{ha}$ caused by the Pod-borer have been reported, with damage to pods ranging from $30-40 \%$ to 90 95\% (Dhaliwal et al., 2010). Economic damage is the greatest in cotton and vegetables. 
Use of chemical pesticides has played a positive role in increasing agricultural productivity and in making India selfsufficient in food grain production. Due to misuse and overuse of these chemical insecticides, resistance has developed in many insects resulting in increased survival rate of the insect pests. There is an urgent need for alternatives of these chemical pesticides. Biopesticides are eco-friendly pesticides which are obtained from naturally occurring substances (biochemicals), microbes and plants. The potential benefits to agriculture and public health programs through the use of biopesticides are considerable. Through the use broader use of biopesticides, agriculture and health programs can be beneficially affected. However, in India, some of the biopesticides like Bacillus thuringiensis (Bt), nucleopolyhedroviruses (NPV), neembased pesticides, Trichoderma etc. have already been registered and are being used.

Farmers are faced with increasing problems of controlling insecticide resistant Helicoverpa. Excessive use of pesticides led to the creation of new strains of pests resistant to synthetic insecticides as well as to the available bio-pesticides like $B t$. cry proteins. The resistance development is often related to receptors modification that involves the mechanisms and targets of action. Due to the results of resistance, there is an urgent need to synthesize novel compounds with insecticidal activity against Pod-borer.

\section{Studies related to Halicoverpa armigera and their biocontrol}

\section{National status}

Pest infestation in different regions and different crops has been demonstrated with several studies. Many researchers studied the harmful effects of Halicoverpa armigera on different crops. Some of them are as follows:
Dinesh et al., (2017) evaluated the yield losses caused by Helicoverpa armigera (Hubner) infesting Chickpea. The loss estimation due to insect pests on Chickpea showed that mean plant height under treated conditions were 1.10 and 1.11 times greater than when unprotected. The mean number of pods was 1.25 and 1.32 times more when the crop was protected. Mean number of damaged pods was 5.44 and 5.12 times more and the mean percent pod damage was 6.76 and 6.86 times greater under unprotected conditions. Similarly, the mean seed per pod was 1.68 and 1.70 times more in protected plots than in unprotected plots. Mean yield/plant (g) and mean yield/plot (g) were 2.09 and 2.19 and 1.43 and 1.45 times greater when the crop was protected. On the basis of yield, avoidable losses of $29.93 \%$ and $31.28 \%$ were recorded due to $H$. armigera infestation in Chickpea variety GNG 1581.

Patra et al., (2016) reported the extent of the crop losses in Pigeon pea (Var: Bahar) due to pest complexes during the 2009-10 and 201011 growing seasons. A total of 41 insect species, consisting of 11 Coleoptera, 13 Hemiptera, 3 Orthoptera, 1 Diptera, 1 Thysanoptera, 11 Lepidoptera, and 1 Hymenoptera were recorded. Results revealed that pod-boring insects $(H$. armigera, $L$. boeticus, A. clavipes and M. obtusa) caused major crop losses to pigeon pea. The national status of the production of bio-pesticides in the proposed area can be reviewed with the help of earlier research. The strategies being used/worked out in India have been reported as follows:

Gopalakrishnan et al., (2017) isolated and identified a toxic metabolite that can be used against $H$. armigera from a previously characterised Streptomyces species (strain CAI-155). The purified metabolite showed 70-78\% mortality for 2 nd instar $H$. armigera larvae by diet impregnation assay, detached leaf assay, and greenhouse assay. The $\mathrm{LD}_{50}$ 
and $\mathrm{LD}_{90}$ values of the purified metabolite were 627 and 2276 ppm, respectively. They proposed that this novel metabolite can be exploited for pest management in future.

Sreekanth et al., (2012) evaluated the efficacy of different biopesticides against the Gram Pod-borer, Helicoverpa armigera (Hubner) and the Legume Pod-borer, Maruca vitrata (Geyer) on Pigeon pea. The per cent inflorescence damage due to Legume Podborer was lowest in spinosad $45 \% \mathrm{SC}$ at $73 \mathrm{~g}$ a.i/ha (4.74\%), followed by Bacillus thuringiensis-1 at $1.5 \mathrm{~kg} / \mathrm{ha}(10.52 \%)$ and Beauveria bassiana SC formulation at 300 $\mathrm{mg} / \mathrm{Lt}$ (14.15\%) with $80.9 \%, 57.6 \%$, and $42.9 \%$ reduction over controls, respectively.

The pod damage due to $M$. vitrata was the lowest in spinosad (17.38\%), followed by Bt.$1(27.57 \%)$, and B. bassiana SC formulation at $300 \mathrm{mg} / \mathrm{lt}(33.82 \%)$ compared with the controls $(45.84 \%)$ with $62.1 \%, 39.9 \%$, and $26.2 \%$ reduction over controls, respectively.

Anshul et al., (2013) prepared methanolic extract of powdered A. апnиa leaves and different compounds isolated from the extract for toxicity and inhibition/ disruption of growth and development of the African Podborer, Helicoverpa armigera (Hübner) (Lepidoptera: Noctuidae).

The methanol extract severely affected $100 \%$ of the larva treated Larvae gained very little weight, some larvae died, some formed larval-pupal intermediates, and a few abnormal adults (adultoids) emerged.

Patel et al., (2011) conducted an experiment on molecular characterization of novel serovars of Bacillus thuringiensis isolates from India. Novel Bacillus thuringiensis isolates GS4, GN24 and UP1 were isolated and characterized by determination of serotyping, insecticidal protein by SDSPAGE, plasmid composition, cry gene content and insect toxicity. Isolate GS4 was toxic to lepidopteran insect larvae of Helicoverpa armigera, but UP1 did not showed any toxicity.

\section{International status}

There is a global effort to identify and produce bio-pesticides using microorganisms or plant extracts. The international status of this is represented by the following journal articles:

Arasu et al., (2013) conducted an experiment in collaboration with Saudi Arabia, Korea and India. They studied antifeedant, larvicidal, and growth inhibitory bioactivities of a novel polyketide metabolite isolated from Streptomyces sp. AP-123 against Helicoverpa armigera and Spodoptera litura. They found the polyketide metabolite presented significant antifeedant activities against $H$. armigera $(78.51 \%)$ and S. litura $(70.75 \%)$ at $1000 \mathrm{ppm}$ concentration. The metabolite also exhibited high larvicidal activities against $H$. armigera (63.11\%) and S. litura $(58.22 \%)$ and the $\mathrm{LC}_{50}$ values were $645.25 \mathrm{ppm}$ for $H$. armigera and $806.54 \mathrm{ppm}$ for S. litura.

Mahmudunnabi et al., (2013) developed the biorational-based integrated pest management package against the Pod-borer, $H$. armigera Hubner infesting Chickpea.

They conducted an experiment in Bangladesh during rabi 2012-13 to evaluate different biorational based IPM packages viz., IPM package 1 (P1) comprising pheromone trapping of $H$. armigera along with sequential release of the biocontrol agents Trichograma evanescens at $\mathrm{gm} / \mathrm{ha} /$ week + Bracon hebetor at 1 jar (1000-1200 adults)/ha/week, and spraying of Bacillus thuringiensis (Bt) at $0.4 \mathrm{~g} /$ litre of water; IPM package 2 (P2) consists of pheromone trapping in addition to sequential release of bio-control agents and spraying of Helicoverpa nuclear polyhedrosis 
virus (HNPV) at $0.1 \mathrm{~g} / \mathrm{L}$ of water against this pest attacking Chickpea. Results indicated that the IPM package (P2) revealed the best performance reducing $68.20 \%$ pod damage over control and provided significantly the highest yield $(1832.20 \mathrm{~kg} / \mathrm{ha})$.

Wubneh (2016) worked on the biological control of Chickpea Pod-borer, Helicoverpa armigera Hubner in Ethiopia. According to his study, most natural populations of $H$. armigera have at least some degree of infection by species-specific NPVs. When the degree of NPV infection can be enhanced, $H$. armigera larval population can be decimated, without deleterious effects on any other organisms.

Sun et al., (2006) conducted an experiment entitled as modelling biological control with wild-type and genetically modified baculoviruses in the Helicoverpa armigeracotton system in China and Netherland. They developed comprehensive model to simulate virus epizootics in a stage structured insect population and analyse scenarios for the biological control of cotton bollworm (CBW), Helicoverpa armigera, in cotton, using wildtype or genetically modified baculoviruses.

In simulations on dosage and timing of a wild-type strain and a genetic recombinant of $H$. armigera single nucleocapsid nucleopolyhedrovirus (HaSNPV), the economic injury level was not exceeded against a prevailing population of 12 larvae per $\mathrm{m}^{2}$ when virus was applied 10 times during the season. They suggested that the model may be used as a decision tool for evaluating virus application strategies in interaction with virus genotype and climatic conditions that affect the phenology and population dynamics of CBW.

Some groups of researchers studied the resistance in insect against the available biopesticides as follows:
Chakroun et al., (2016) presented a study on the characterization of the resistance to Vip3Aa in Helicoverpa armigera from Australia and the role of midgut processing and receptor binding. They discussed that insect resistant cotton and maize expressing the Bt Vip3Aa protein were recently commercialized, though not yet in Australia. They found that, although relatively high, the frequency of alleles for resistance to Vip3Aa in field populations of $H$. armigera in Australia did not increase over the past four seasons until 2014/15. According to this study Vip3Aa-resistance did not confer crossresistance to Cry1Ac or Cry2Ab. Vip3Aa was labelled with ${ }^{125} \mathrm{I}$ and used to show specific binding to $H$. armigera brush-border membrane vesicles (BBMV). Binding was of high affinity $(K d=25$ and $19 \mathrm{nM}$ for susceptible and resistant insects, respectively) and the concentration of binding sites was high $(R t=140 \mathrm{pmol} / \mathrm{mg}$ for both). Despite the narrow-spectrum resistance, binding of ${ }^{125} \mathrm{I}$ labeled Vip3Aa to BBMV of resistant and susceptible insects was not significantly different. Proteolytic conversion of Vip3Aa protoxin into the activated toxin rendered the same products, though it was significantly slower in resistant insects.

Agriculture is the back bone of all developing countries and it's at high risk due to biotic as well as abiotic stress. Insects cause major loss in food crops and country has to suffer a lot. Halicoverpa armigera is an economic important insect which destroys the Chick pea crop badly. Chemical pesticides played a vital role following by their negative impact on environment as well as on human health.

Microbes are the rich sources of metabolites with their unique properties. With the help of these microbial isolated, bio insecticides are being manufactured and they are safe as well as eco-friendly. As these are novel compounds, so the chances of existing resistance are also low. 


\section{Future aspects}

The make aim to draw a thought in this direction is to reveal the need of new potent strains of bacteria as bio pesticides. As the future aspect of my presentation, a new bacterial culture is to be identified followed by bioformulation against Helicoverpa armigera.

\section{References}

Anshul, N., Bhakuni, R. S., Gaur, R. and Singh, D. 2013. Isomeric flavonoids of artemisia annua (asterales: asteraceae) as insect growth inhibitors against Helicoverpa armigera (Lepidoptera: Noctuidae). Florida Entomologist, 96(3)

Arasu, M. V., Al-Dhabi, N. A., Saritha, V., Duraipandiyan, V., Muthukumar, C. and Kim, S.J. 2013. Antifeedant, larvicidal and growth inhibitory bioactivities of novel polyketide metabolite isolated from Streptomyces sp. AP-123 against Helicoverpa armigera and Spodoptera litura BMC Microbiology, 13(105)

Chakroun, M., Banyuls, N., Bel, Y., Escriche, B. and Ferré, J. 2016. Correction for Bacterial Vegetative Insecticidal Proteins (Vip) from Entomopathogenic Bacteria, Microbiology and Molecular Biology Reviews 80(3)

Dhaliwal, G.S., Jindal, V. and Dhawan, A.K. 2010. Insect Pest Problems and Crop Losses: Changing Trends. Indian Journal of. Ecology., 37(1)

Dinesh, K., Anusha, S., Singh, R. B. and Dangi, N. L. 2017. Estimation of avoidable yield losses caused by Helicoverpa armigera (Hubner) on chickpea, Journal of Entomology and Zoology Studies; 5(2)
Gopalakrishnan, S., Rajendran, V., Arumugam, S., Sharma, H. C., Vadlamudi, S., Bhimineni, R. K., Gonzalez, S. V., Melo, T. M. and Simic, N. 2016. Insecticidal activity of a novel fatty acid amide derivative from Streptomyces species

against Helicoverpa armigera, Natural Product Research Formerly Natural Product Letters 30(24)

Mahmudunnabi, M., Dutta, N. K., Rahman, A. K. M. Z. and Alam, S. N. 2013. Development of biorational-based integrated pest management package against pod borer, Helicoverpa armigera Hubner infesting chickpea, Journal of Biopesticides 6(2)

Patel, K. D., Chudasama, C. J., Ingle, S. S. 2011. Molecular characterization of Bacillus thuringiensis isolated from diverse habitats of India, Journal of Basic Microbiology 52(4)

Patra, S., Firake, D. M., Thakur N. S. A. and Roy, A. 2016. Insect pest complex and crop losses in pigeon pea in medium altitude hill of Meghalaya, The Bioscan 11(1)

Sreekanth, M. and Seshamahalakshmi, M. 2012. Studies on relative toxicity of biopesticides to Helicoverpa armigera (Hubner) and Maruca vitrata (Geyer) on Pigeonpea (Cajanus cajan L.), Journal of Biopesticides $5(2)$

Sun, X., Werf, W. V. D., Bianchi, F.J.J.A. and Vlak, J.M. 2006. Modeling Modeling biological control with wild-type and genetically modified baculoviruses in the Helicoverpa armigera-Cotton system. Ecological Modelling 221

Wubneh, W. Y. 2016. Biological control of chickpea pod borer, Helicoverpa armigera Hubner (Lepidoptera: Noctuidae): A global concern, World Scientific News 45(2)

\section{How to cite this article:}

Divya Srivastava, Adesh Kumar, Poonam C. Singh, Suchi Srivastava, Shalini Srivastava, Ashutosh Tiwari, Praveen Tiwari, Bhawna Mathur, Jasvant Singh and Arun Kumar. 2017. Short Presentation of the Studies on Miocrobial Metabolites as Eco Friendly Insecticides against Halicoverpa armigera. Int.J.Curr.Microbiol.App.Sci. 6(12): 3828-3832.

doi: https://doi.org/10.20546/ijcmas.2017.612.441 